\title{
Comparative Study on the Nutritional and Anti-Nutritional Compositions of Sweet and Bitter Cassava Varieties for Garri Production
}

\section{Obueh $\mathrm{HO}^{1}$ and Kolawole $\mathrm{SE}^{* 2}$}

\author{
${ }^{1}$ Biology Department, College of Education, Ekiadolor, Benin City, Edo State, Nigeria \\ ${ }^{2}$ National Open University of Nigeria, Benin Study Centre, Benin City, Edo State, Nigeria
}

${ }^{*}$ Corresponding author: Kolawole SE, National Open University of Nigeria, Benin Study Centre, Benin City, Edo State, Nigeria, E-mail: kolasunde@gmail.com

Citation: Obueh HO, Kolawole SE (2016) Comparative Study on the Nutritional and Anti-Nutritional Compositions of Sweet and Bitter Cassava Varieties for Garri Production. J Nutr Health Sci 3(3): 302. doi: $10.15744 / 2393-9060.3 .302$

\section{Received Date: May 31, 2016 Accepted Date: August 23, 2016 Published Date: August 25, 2016}

\begin{abstract}
A comparative study on the proximate, mineral amino acid and anti nutritional compositions of sweet and bitter cassava varieties was done to ascertain the nutritional quality and safety after $72 \mathrm{~h}$ of fermentation for garri production. The sweet cassava variety had higher moisture $(8.04 \pm 0.74 \%)$, crude protein $(23.51 \pm 0.50 \%)$, fat $(10.01 \pm 0.02 \%)$, crude fibre $(5.66 \pm 0.02 \%)$, and ash $(0.44 \pm 0.10 \%)$ contents than the bitter cassava variety with moisture $(7.23 \pm 0.39 \%)$ crude protein $(22.74 \pm 0.16 \%)$, fat $(9.54 \pm 0.01 \%)$, crude fibre $(4.13 \pm 0.02 \%)$ and ash $(0.35 \pm 0.02 \%)$ contents. Of all the minerals analysed, $\mathrm{Ca}, \mathrm{Mg}, \mathrm{P}, \mathrm{Zn}$ and $\mathrm{Cu}$ had higher contents for the sweet cassava variety than the bitter cassava variety. The amino acid contents of the sweet cassava variety were higher than the bitter cassava variety. The contents of the anti-nutrients were higher for the bitter cassava variety with hydrogen cyanide $(20.13 \pm 0.09 \mathrm{mgHCN} / 100 \mathrm{~g})$, oxalate $(3.27 \pm 0.04 \mathrm{mg} / 100 \mathrm{~g})$, tannin $(0.3 \pm 0.00 \%)$, phytate $(62.4 \pm 1.29 \mathrm{mg} / 100 \mathrm{~g})$, alkaloid $(0.32 \pm 0.04 \%)$, lignin $(0.18 \pm 0.01 \mathrm{mg} / 100 \mathrm{~g})$ and saponin $(0.13 \pm 0.01 \%)$ as compared to the sweet cassava variety with hydrogen cyanide $(7.58 \pm 1.25 \mathrm{mgHCN} / 100 \mathrm{~g})$, oxalate $(1.30 \pm 0.02 \mathrm{mg} / 100 \mathrm{~g})$, tannin $(0.2 \pm 0.01 \%)$, phytate $(53.7 \pm 0.81 \mathrm{mg} / 100 \mathrm{~g})$, alkaloid $(0.27 \pm 0.02 \%)$, lignin $(0.13 \pm 0.01 \mathrm{mg} / 100 \mathrm{~g})$ and saponin $(0.13 \pm 0.01 \%)$. The higher nutritional quality and the lower anti-nutrients content demonstrate that the sweet cassava is a better variety for garri production to ensure better health and safety of the consumers.
\end{abstract}

Keywords: Nutritional; Anti-nutritional; Sweet; Bitter; Cassava varieties; Garri

\section{Introduction}

Cassava (Manihot esculenta Crantz), is a perennial woody shrub with an edible starchy tuberous root, which grows in tropical and subtropical areas of the world [1]. It is the third largest source of carbohydrates for human food in the world after rice and corn with Africa being its largest continent of production [2]. The roots are primarily produced for food in the form of garri, fufu and lafun. This is because cassava roots are quite high in carbohydrates containing about 60 to $70 \%$ for Nigerian cultivars [3]. Cassava is classified on the basis of the level of cyanide content into sweet and bitter cassava varieties [4].

Cassava is often identified as an inferior food crop, as poor people's crop and as a dangerous crop [5]. These myths on cassava were due to some limitations in the crop which include the presence of cyanogenic glucosides (which is broken down to release toxic hydrogen cyanide), low protein content and short harvest shelf-life [6]. Traditionally, most of these constraints have been met through processing. Cassava is processed to remove or reduce the toxic cyanogenic glucosides, improve palatability as well as serve as a means of preservation [7]. Fermentation of cassava is the most important and widely used means of processing cassava [8].

The most typical and popular product which is prepared from fermented cassava pulp is garri. Garri is an important food in West Africa, particularly Nigeria, where it is consumed by an estimated 80 million people [9]. Garri is prepared by grating the enlarged roots of the cassava plant and allowing it to ferment naturally with application of pressure in a jute bag. The fermented mash is roasted with or without palm oil added. The nutritional quality of the traditional fermentation of cassava for garri production is very important because garri has two main disadvantages which are carried over from cassava. The first is the presence of toxic cyanogenic glycosides, the consumption of which may lead to ailments such as tropical ataxic neuropathy and goitre, when consumed over prolonged periods in a low protein diet [10]. The other deficiency is its low content of protein and amino acids (IITA, 1990).

Fermentation enhances the nutrient content of cassava through biosynthesis of vitamins, essential amino acids, proteins and fibre digestibility. It also enhances micronutrient bioavailability and aids in degrading antinutritional factors [11]. Proper nutrients in food enhance optimal health and wellbeing [12]. Antinutrients interfere with the absorption of nutrients in the body [13]. The 
aim of this study was to investigate the compositions of sweet and bitter cassava varieties fermented for garri production in order to ensure its adequate nutritional quality for better health of the consumers.

\section{Materials and methods}

\section{Collection of samples}

Freshly harvested sweet and bitter cassava tubers were collected from a local farm in Ekiadolor (Lat $6^{\circ} 29^{\prime} \mathrm{N}$, Long $5^{\circ} 35^{\prime} \mathrm{E}$ ), Ovia North East Local Government Area of Edo State, Nigeria. The tubers were obtained from 10 - 14 month old plants. They were washed with distilled water and peeled. The cassava pulps were then washed thoroughly and separately grated in a clean cassava grinding machine. The sweet and bitter grated cassava were each transferred into separate jute bags and pressure applied in a press (made from wood and concrete) and left to ferment for three days under room temperature. Samples of the sweet and bitter cassava were taken for analyses in the laboratory.

\section{Proximate composition analyses}

Moisture, ash, crude fibre, protein and fat contents were determined using the methods of AOAC and the reducing sugar was determined by the method of $[14,15]$.

\section{Mineral composition analyses}

$\mathrm{Ca}, \mathrm{Mg}, \mathrm{Fe}, \mathrm{Zn}, \mathrm{Mn}, \mathrm{Al}, \mathrm{Pb}$ and $\mathrm{Cu}$ contents were determined using the AAS (Atomic Absorption Spectrometer) by the procedure of $\mathrm{AOAC}, \mathrm{Na}$ and $\mathrm{K}$ contents were determined by flame photometer (AOAC) and phosphorus content was by colorimetric method of AOAC [14].

\section{Amino acid composition analyses}

The amino acid profile (arginine, histidine, lysine, tryptophan, phenylalanine, methionine, threonine, leucine and valine) contents were determined by the method of Uysal, et al. [16].

\section{Anti-nutritional composition analyses}

Total oxalate, phytate, tannin, alkaloid, lignin, saponin and hydrogen cyanide contents were determined. Total oxalate content was determined by the method of AOAC, phytate content was determined by the spectrophotometric method as described by Agoreyo, et al. tannin content was determined by the spectrophotometric method of Jaffe, alkaloid content was determined by the method of Onwuka, lignin content was determined by the method of Morrison, et al. saponin content was determined by the method of Abhishek, et al. and hydrogen cyanide content was determined by the alkaline titration method of AOAC [14,17-21].

\section{Data analysis}

The results were presented as mean \pm standard deviation of triplicate values. A one way analysis of variance (ANOVA) and Duncan Multiple Range test were carried out. Significant difference was accepted at 5\% probability [22].

\section{Results}

The proximate composition of the sweet and bitter cassava varieties is presented in Table 1 . The moisture content of the sweet cassava variety $(8.04 \pm 0.74 \%)$ was significantly higher $(\mathrm{p}<0.05)$ than that of the bitter cassava variety $(7.23 \pm 0.39 \%)$. The crude protein contents were $23.51 \pm 0.50 \%$ and $22.74 \pm 0.16 \%$ for the sweet and bitter cassava varieties respectively. Fat content was higher at $10.01 \pm 0.02 \%$ for the sweet cassava variety than the bitter cassava variety at $9.54 \pm 0.01 \%$. Crude fibre and ash recorded $5.66 \pm 0.02 \%$ and $0.44 \pm 0.10 \%$ for the sweet cassava variety as compared with $4.13 \pm 0.02 \%$ and $0.35 \pm 0.02 \%$ for the bitter cassava variety. Reducing sugar content from carbohydrate breakdown in the sweet cassava variety was lower (33.79 $\pm 0.09 \%)$, though not significantly $(\mathrm{p}>0.05)$, than the bitter cassava variety at $37.04 \pm 0.09 \%$. Na and $\mathrm{K}$ had lower values $(\mathrm{p}>0.05)$ for the sweet cassava variety at $259.64 \pm 1.66 \mathrm{mg} / \mathrm{l}$ and $319.87 \pm 2.75 \mathrm{mg} / \mathrm{l}$ when compared to the bitter cassava variety at $338.66 \pm 6.59 \mathrm{mg} / \mathrm{l}$ and $431.96 \pm 7.23$ $\mathrm{mg} / \mathrm{l} \mathrm{respectively} \mathrm{(Table} \mathrm{2).} \mathrm{Ca,} \mathrm{Mg}$ and P contents were $224.57 \pm 4.16 \mathrm{mg} / \mathrm{l}, 35.17 \pm 4.65 \mathrm{mg} / \mathrm{l}$ and $593.73 \pm 5.82 \mathrm{mg} / \mathrm{l}$ respectively for the sweet cassava variety and $187.53 \pm 5.19 \mathrm{mg} / \mathrm{l}, 28.67 \pm 1.62 \mathrm{mg} / \mathrm{l}$ and $402.37 \pm 5.83 \mathrm{mg} / \mathrm{l}$ respectively for the bitter cassava variety. $\mathrm{Fe}, \mathrm{Mn}, \mathrm{Al}$ and $\mathrm{Pb}$ contents were higher in the bitter cassava variety than in the sweet cassava variety. $\mathrm{Zn}$ and $\mathrm{Cu}$ were significantly higher in the sweet cassava variety $(20.85 \pm 1.60 \mathrm{mg} / \mathrm{l}$ and $3.96 \pm 0.25 \mathrm{mg} / \mathrm{l})$ than in the bitter cassava variety $(16.84 \pm 1.74 \mathrm{mg} / \mathrm{l}$ and $3.71 \pm 0.07 \mathrm{mg} / \mathrm{l})$. The amino acid profile of the sweet and bitter cassava varieties is shown in Table 3 . The bitter cassava variety had lower values for all the amino acids analyzed than the sweet cassava variety. In Table 4 is shown the anti-nutritional composition of the sweet and bitter cassava varieties. All the anti-nutrients had higher values for the bitter cassava variety than the sweet cassava variety. Hydrogen cyanide content was $7.58 \pm 1.25 \mathrm{mg} \mathrm{HCN} / 100 \mathrm{~g}$ and $20.13 \pm 0.09 \mathrm{mgHCN} / 100 \mathrm{~g}$, oxalate content was $1.30 \pm 0.02$ $\mathrm{mg} / 100 \mathrm{~g}$ and $3.27 \pm 0.04 \mathrm{mg} / 100 \mathrm{~g}$, for the sweet and bitter cassava varieties respectively. The concentration of phytate was highest in the cassava varieties with $53.7 \pm 0.81 \mathrm{mg} / 100 \mathrm{~g}$ for the sweet cassava and $62.4 \pm 1.29 \mathrm{mg} / 100 \mathrm{~g}$ for the bitter cassava. Alkaloid concentration was $0.27 \pm 0.02 \%$ and $0.32 \pm 0.04 \%$ for the sweet and bitter cassava varieties respectively. The values for lignin and saponin were significantly higher $(\mathrm{P}<0.05)$ in the sweet cassava variety than the bitter cassava variety. 


\begin{tabular}{|c|c|c|}
\hline \multicolumn{3}{|c|}{ Cassava Varieties } \\
\hline Parameter (\%) & Sweet & Bitter \\
\hline Moisture & $8.04 \pm 0.74^{\mathrm{b}}$ & $7.23 \pm 0.39^{\mathrm{a}}$ \\
\hline Crude Protein & $23.51 \pm 0.50^{\mathrm{b}}$ & $22.74 \pm 0.16^{\mathrm{b}}$ \\
\hline Fat & $10.01 \pm 0.02^{\mathrm{b}}$ & $9.54 \pm 0.01^{\mathrm{a}}$ \\
\hline Crude Fibre & $5.66 \pm 0.02^{\mathrm{b}}$ & $4.13 \pm 0.02^{\mathrm{c}}$ \\
\hline Ash & $0.44 \pm 0.10^{\mathrm{c}}$ & $0.35 \pm 0.02^{\mathrm{c}}$ \\
\hline Reducing sugar & $33.79 \pm 0.09^{\mathrm{b}}$ & $37.04 \pm 0.09^{\mathrm{b}}$ \\
\hline
\end{tabular}

Values are means \pm standard deviation $(n=3)$. Means in the same row for each variety with same superscript are not significantly different $(P>0.05)$ Table 1: Proximate composition of sweet and bitter cassava varieties

\begin{tabular}{|c|c|c|}
\hline \multicolumn{3}{|c|}{ Cassava Varieties } \\
\hline Parameters (mg/l) & Sweet & Bitter \\
\hline Calcium $(\mathbf{C a})$ & $224.57 \pm 4.16^{\mathrm{b}}$ & $187.53 \pm 5.19^{\mathrm{a}}$ \\
\hline Magnesium $(\mathbf{M g})$ & $35.17 \pm 4.65^{\mathrm{b}}$ & $28.67 \pm 1.62^{\mathrm{b}}$ \\
\hline Sodium $(\mathbf{N a})$ & $259.64 \pm 1.66^{\mathrm{c}}$ & $338.66 \pm 6.59^{\mathrm{c}}$ \\
\hline Potassium (K) & $319.87 \pm 2.75^{\mathrm{c}}$ & $413.96 \pm 7.23^{\mathrm{c}}$ \\
\hline Phosphorus $(\mathbf{P})$ & $593.73 \pm 5.82^{\mathrm{a}}$ & $402.37 \pm 5.83^{\mathrm{a}}$ \\
\hline Iron $(\mathbf{F e})$ & $75.49 \pm .72^{\mathrm{b}}$ & $124.55 \pm 2.34^{\mathrm{b}}$ \\
\hline Zinc $(\mathbf{Z n})$ & $20.85 \pm 1.60^{\mathrm{b}}$ & $16.84 \pm 1.74^{\mathrm{a}}$ \\
\hline Manganese (Mn) & $3.31 \pm 0.09^{\mathrm{d}}$ & $3.97 \pm 0.15^{\mathrm{c}}$ \\
\hline Aluminium (Al) & $1.78 \pm 0.20^{\mathrm{b}}$ & $2.04 \pm 0.15^{\mathrm{a}}$ \\
\hline Lead $(\mathbf{P b})$ & $0.83 \pm 0.10^{\mathrm{b}}$ & $1.05 \pm 0.24^{\mathrm{b}}$ \\
\hline Copper $(\mathbf{C u})$ & $3.96 \pm 0.25^{\mathrm{a}}$ & $3.71 \pm 0.07^{\mathrm{b}}$ \\
\hline
\end{tabular}

Values are means \pm standard deviation $(\mathrm{n}=3)$; means in the same row for each variety with same superscript are not significantly different $(\mathrm{P}>0.05)$ Table 2: Mineral composition of sweet and bitter cassava varieties

\begin{tabular}{|c|c|c|}
\hline \multicolumn{3}{|c|}{ Cassava Varieties } \\
\hline Parameter $(\mathbf{g} / \mathbf{1 0 0 g})$ & Sweet & Bitter \\
\hline Arginine & $12.75 \pm 0.48^{\mathrm{a}}$ & $8.27 \pm 0.14^{\mathrm{a}}$ \\
\hline Histidine & $3.57 \pm 1.07^{\mathrm{a}}$ & $1.87 \pm 0.42^{\mathrm{c}}$ \\
\hline Lysine & $4.15 \pm 0.20^{\mathrm{a}}$ & $1.85 \pm 0.06^{\mathrm{a}}$ \\
\hline Tryptophan & $1.73 \pm 0.00^{\mathrm{a}}$ & $0.92 \pm 0.06^{\mathrm{a}}$ \\
\hline Phenylalanine & $2.15 \pm 0.13^{\mathrm{a}}$ & $1.72 \pm 0.01^{\mathrm{a}}$ \\
\hline Methionine & $2.39 \pm 0.05^{\mathrm{a}}$ & $1.97 \pm 0.06^{\mathrm{b}}$ \\
\hline Threonine & $5.11 \pm 2.09^{\mathrm{a}}$ & $4.24 \pm 0.70^{\mathrm{c}}$ \\
\hline Leucine & $18.70 \pm 5.08^{\mathrm{a}}$ & $16.71 \pm 2.19^{\mathrm{a}}$ \\
\hline Valine & $13.90 \pm 7.76^{\mathrm{a}}$ & $8.72 \pm 0.31^{\mathrm{a}}$ \\
\hline
\end{tabular}

Values are means \pm standard deviation $(\mathrm{n}=3)$; means in the same row for each variety with same superscript are not significantly different $(\mathrm{P}>0.05)$ Table 3: Amino acid profile of sweet and bitter cassava varieties

\begin{tabular}{|c|c|c|}
\hline \multicolumn{3}{|c|}{ Cassava Varieties } \\
\hline Parameter & Sweet & Bitter \\
\hline $\begin{array}{c}\text { Hydrogen Cyanide } \\
\text { (mgHCN/100g) }\end{array}$ & $7.58 \pm 1.25^{\mathrm{a}}$ & $20.13 \pm 0.09^{\mathrm{a}}$ \\
\hline Oxalate (mg/100g) & $1.30 \pm 0.02^{\mathrm{c}}$ & $3.27 \pm 0.04^{\mathrm{c}}$ \\
\hline Tannin (\%) & $0.2 \pm 0.01^{\mathrm{a}}$ & $0.3 \pm 0.00^{\mathrm{b}}$ \\
\hline Phytate (mg/100g) & $53.7 \pm 0.81^{\mathrm{c}}$ & $62.4 \pm 1.29^{\mathrm{a}}$ \\
\hline Alkaloid (\%) & $0.27 \pm 0.02^{\mathrm{a}}$ & $0.32 \pm 0.04^{\mathrm{a}}$ \\
\hline Lignin (mg/100g) & $0.13 \pm 0.01^{\mathrm{b}}$ & $0.18 \pm 0.01^{\mathrm{a}}$ \\
\hline Saponin (\%) & $0.13 \pm 0.01^{\mathrm{b}}$ & $0.21 \pm 0.01^{\mathrm{a}}$ \\
\hline
\end{tabular}

Values are means \pm standard deviation $(n=3)$; means in the same row for each variety with same superscript are not significantly different $(P>0.05)$ Table 4: Antinutritional composition of sweet and bitter cassava varieties 


\section{Discussion}

The higher moisture, crude protein, fat, crude fibre and ash contents of the sweet cassava variety than the bitter cassava indicates that the sweet cassava variety is a better source of lipid, nitrogenous compounds and cellulose than the bitter cassava variety. This is in agreement with the study of Sarkiyayi and Agar [13] who reported higher moisture, ash, lipid contents in sweet cassava variety than bitter cassava variety. Since ash content is a measure of the total minerals present within a food, a reduction in its level is as a result of the minerals being used by the microorganisms during fermentation [23]. The reduction of the carbohydrate content of the cassava varieties to reducing sugar was due to the production of hydrolytic enzymes by the microbial flora present which they used as carbon source and transformed them to other macromolecules or metabolites such as protein and fat [4]. The reducing sugar content reduced as fermentation progressed. Panda, et al. demonstrated that Lactobacillus plantarum could produce a amylase and reducing sugars from hydrolyzed starch and convert them into energy for their growth hence the carbohydrate was degraded faster to reducing sugar in the sweet cassava variety [24].

The evaluation of minerals in cassava is an important exercise from nutritional to the toxicological point of view [25]. This is because some of the metals have long term effects on human health when accumulated in target organs. The higher Ca, Mg, $\mathrm{P}, \mathrm{Zn}$ and $\mathrm{Cu}$ contents in the sweet cassava variety than the bitter cassava is comparable with the study of Oboh and Elusiyan [5]. Metal deficiency syndrome like rickets and calcification of bones is caused by calcium deficiency [26]. Magnesium deficiency in man is responsible for severe diarrhea, migranes, hypertension, cardiomyopathy, arteriosclerosis and stroke [27]. It plays fundamental roles in most reactions involving phosphate transfer [28]. Phosphorus is involved in the intermediary metabolism of carbohydrates and it is a pre-requisite for bone and teeth structures [29]. Zinc is necessary for protein and nucleic acid synthesis and normal body development. The higher $\mathrm{Zn}$ content in the sweet cassava variety could be attributed to the reduced phytate content [5]. According to Reddy and Love, copper is needed for growth, production of bones, teeth, hair, blood, nerves, skin, vitamins and hormones. The concentrations of $\mathrm{Na}, \mathrm{K}, \mathrm{Mn}, \mathrm{Al}, \mathrm{Fe}$ and $\mathrm{Pb}$ were higher $(\mathrm{P}>0.05)$ in the bitter cassava variety than the sweet cassava variety in agreement with the study of Oboh and Elusiyan [5,30]. Sodium salts which are soluble in aqueous phase play important roles in transportation of metabolites in the body. Potassium takes part in ionic balance and tissue excitability. The low concentration of some of the micro elements was similar to that reported by Cardoso, et al. [31]. This could be due to the use of organic fertilizers by the local cassava farmers.

Amino acids serve as substrates for protein synthesis and play other roles as tissue repairs, hormone synthesis and precursors of heme as well as synthesis of enzymes that catalyze biochemical reactions in cells [32]. This study showed higher amino acid contents in the sweet cassava variety than the bitter cassava variety in comparison with the study of Aro and Aletor [33]. The presence of these eight essential and one non-essential amino acids in the cassava varieties would enhance its nutritive value with respect to its protein content and as well as releasing other materials exclusively in the consumed garri [34].

The anti-nutritional compositions of the cassava after fermentation agreed with the study of Oboh and Oladunmoye [35]. These anti-nutrients are used by the plant probably for defense [36]. The lower concentration of antinutrients in the sweet cassava variety corroborated with the study of Aro, et al. on cassava starch residues. Cyanide is poisonous because it binds with cytochrome oxidase and stops its action in respiration in the body [37]. The concentration of hydrogen cyanide in the fermented cassava varieties is lower that the lethal dose of between 30 and $210 \mathrm{mgHCN} / 100 \mathrm{~g}$ [5]. Oxalic acid and its salts occur as end products of metabolism in a number of plant tissues. Oxalates can bind to calcium and other metals rendering these metals unavailable for normal physiological and biochemical roles such as maintenance of strong bones, teeth and nerve transmission [38]. Tannin affects nutritive value of food forming complex with protein (both substrate and enzyme) thereby inhibiting digestion and absorption [36]. The tannin content in this study was below the detrimental dose of $0.7-0.9 \%$. Phytate is capable of chelating divalent cationic minerals like calcium, iron, magnesium and zinc thereby inducing dietary deficiency [39]. The phytate content of the fermented cassava varieties in this study was far below that of cassava flour in the study of Oboh and Elusiyan [5]. Wise suggested that the solubility of phytate and proportion of minerals bound to the complex depend on dietary calcium levels [40]. The high calcium levels could be attributed to the low phytate content in this study. The alkaloid content for both cassava varieties was comparable with that of cassava starch residues in the study of Aro, et al. [37]. Though alkaloids comprise a large group of nitrogenous compounds widely used as cancer chemotherapeutic agents, they interfere with cell division and almost uniformly invoke bitter taste in foods [41].

Lowering the size of cassava favours lignin degradation [42]. The low lignin content in this study indicated breakdown action by microorganisms during the fermentation process [43]. Saponins are phytonutrients found in particular abundance in various plant species are grouped by the soap-like foaming they produce when shaken in aqueous solution. Saponins when present in large amounts impart bitter taste to plant food and induce haemolysis and cholesterol binding [44]. These anti-nutrients form complexes with metals. The lower concentration of the anti-nutients in the sweet cassava variety than the bitter cassava variety may enhance absorption when they form complexes with these metals.

\section{Conclusion}

The processing of the cassava varieties into garri by fermentation enhances micronutrient availability, improves nutritional value and aids in degrading anti-nutritional factors. The higher nutritional and lower anti-nutritional quality of the sweet cassava variety than the bitter cassava variety makes sweet cassava a better variety for garri production. 


\section{References}

1. Burrell MM (2003) Starch: The need for improved quality or quantity - An overview. J Exp Bot 218: 451-6.

2. Soryotha S, Kyu KL, Ratanakhanokcha K (2010) An efficient treatment for detoxification process of cassava starch by plant cell wall degrading enzymes. J Biosci Bioeng 109: 9-14.

3. NRCRI (2004) Guide to cassava cultivation in Nigeria. National Root Crops Research Institute, Umudike 121.

4. Oboh G, Akindahunsi AA, Oshodi AA (2002) Nutrient and antinutrient contents of Aspergillus niger fermented cassava products (flour and garri). J Food Comp and Analy 15: 617-22.

5. Oboh G, Elusiyan CA (2007) Changes in the nutrient and antinutrient contents of micro-fungi fermented cassava flour produced from low and medium cyanide variety of cassava tubers. African J Biotechnol 6: 2150-7.

6. Oyewole OB (1995) Application of biotechnology of cassava processing in Africa: In Transformation Alinentaire du Manioc. T. Agbor Egbe, A. Brauman, D. Griffon, S. Treche (eds) 1995 editions ORSTOM 277-86.

7. Yeoh HH, Sun F (2001) Assessing cyanogens content in cassava-based food using the enzyme dipstick method. Food Chem Toxicol 39: 649-53.

8. Oyewole OB (1992) Cassava processing in Africa In: Applications of Biotechnology in fermented foods. The National Academics Press Washington DC 89-92.

9. Okafor N, Umeh C, Ibenegbu C (1998) Amelioration of garri, a fermented food derived from cassava (Manihot esculenta Crantz) by microbial inoculation. World J Microbiol Biotech 14: 835-8.

10. Okafor N, Okeke BC, Umeh C, Ibenegbu C (1999) Secretion of lysine in a broth medium of lactic acid bacteria and yeasts associated with garri production using a synthetic gene. Letters in Applied Microbiology 28: 419-22.

11. Achinewhu SC, Barber L, Ijeoma IO (1998) Physicochemical properties and gratification of selected cassava cultivars in Rivers State, Nigeria. Plant Food for Human Nutrition 52: 133-40.

12. Thomas MD (2006) Text Book of Biochemistry $6^{\text {th }}$ Edn, Wiley - Liss, USA 1080-4.

13. Sarkiyayi S, Agar TM (2010) Comparative analysis on the nutritional and antinutritional contents of the sweet and bitter cassava varieties. Advance J Food Science and Technol 2: 328-34.

14. AOAC (2005) Association of Official Analytical Chemists. Official Methods of Analysis $18^{\text {th }} \mathrm{edn}$. Washington DC, USA.

15. Kimaryo VW, Massawi GA, Olasupo NA, Holzapfel WH (2000) The use of a starter culture in the fermentation of cassava for the production of 'kivunde' a traditional Tanzanian food product. Int J Food Microbiol 56: 176-90.

16. Uysal H, Aydogan NM, Algur FO (2002) Effect of single cell protein as a protein source in drosophila culture. Brazilian Journal of Microbiology 33: 314-7.

17. Agoreyo BO, Obansa ES, Obanor EO (2012) Compararive nutritional and phytochemical analyses of two varieties of Solanum melongena. Scien World J 7: 5-8.

18. Jaffe CS (2003) Analytical Chemistry of foods. Blackie Academic and Professional, New York 1: 200.

19. Onwuka GI (2005) Food Analysis and Instrumentation. Naphohia Prints. $3^{\text {rd }}$ edn, A Division of HG Support Nigeria Ltd 133-61.

20. Morrison IM, Asiedu EA, Stuchbury T, Powell AA (1995) Determination of lignin and tannin contents of cowpea seed coats. Annuals of Botany 76: 287-90.

21. Abhishek M, Satish KV, Santosh KS, Prasad GBKS, Dua VK (2011) Investigation of the antimicrobial, antioxidant and anti-inflammatory activity of compound isolated from Murraya koenigii. Inter J Appli Biol and Pharmaceu Technol 2: 470-7.

22. Ogbeibu AE (2005) Biostatistics. A practical approach to research and data handling. Mindex Publishing Co. Ltd., Benin City 264.

23. Aderiye BJ, Ogunjobi AA (1998) Fermentation of yam: microbiology and sensory evaluation of cooked fermented yam tissues. Plant Foods for Human Nutri 52: 49-54.

24. Panda SH, Swan MR, Kar S, Ray RC, Montet D (2008) Statistical optimization of $\alpha$ - amylase production by Lactobacillus plantarum MTCC 1407 in submerged fermentation. Polish J Microbiol 57: 149-55.

25. Njuguna DG, Wanjoko JK, Kinyanjui T, Wachira FN (2013) Mineral elements in Kenyan tea seed oil cake. Interna J Resear in Chemistry and Environ 3: $253-61$.

26. Dahouervon - Ahoussi E, Adjou ES, Lozes E, Yehouenon LL, Hounye R, et al. (2012) Nutritional and microbiological characterization of pulp powder of locust bean (Parkia boglobosa Benth) used as a supplement in infant feeding in Northern Benin. African J Food Sci 6: 232-8.

27. Appel LJ (1999) Nonpharmacologic therapies that reduce blood pressure: A fresh perspective. Clin Cardiol 22: 1111-5.

28. Bello MO, Falade OS, Adewusi SRA, Olawore NO (2008) Studies on the chemical compositions and antinutrients of some lesser known Nigerian fruits. African J Biotechnol 7: 3972-9.

29. Mason JB (2011) Vitamins, trace minerals and other micronutrients. In Goldman L, Schafer Al, eds Goldman's Cecil Medicine, $24^{\text {th }}$ edn, Elsevier Saunders Philadelpia PA, United States.

30. Reddy MB, Love M (1999) The impacts of food processing on the nutritional quality of vitamins and minerals. Adv Exp Med Biol 459: 99-106.

31. Cardoso AP, Mirione E, Ernesto M, Massaza F, Cliff J, et al. (2005) processing of cassava roots to remove cyanogens. Short communication. J Food Composition and Analy 18: 451-60.

32. Maduka HCC, Okoye ZSC, Mahmood M (2004) Amino acids and anionic components of Sacoglottis gaboensis of stem bark extract, a Nigerian alcoholic beverage additive. J Biolo Sci 4: 55-61.

33. Aro SO, Aletor VA (2012) Proximate composition and amino acid profile of differently fermented cassava tuber wastes collected from a cassava starch producing factory in Nigeria. Livestock Research for Rural Development 24: 1-5.

34. Ezekiel OO, Aworh OC, Blaschek HP, Ezeji TC (2010) Protein enrichment of cassava peel by submerged fermentation with Trichoderma viride (ATCC 36319). African J Biotechnol 9: 187-94.

35. Oboh G, Oladunmoye MK (2007) Biochemical changes in microfungi fermented cassava flour produced from low and medium cyanide variety of cassava tubers. Nutrition and Health 18: 355-67.

36. Aletor VA (1993) Allelochemicals in plant food and feeding stuffs: nutritional, biochemical and physiopathological aspects in animal production. Vet Hum Toxicol 35: 57-67.

37. Aro SO, Aletor VA, Tewe OO, Fajemisan AN, Usifo B, et al. (2008) Preliminary investigation on the nutrients, antinutrients and mineral composition of microbially fermented cassava starch residues. Proc $33^{\text {rd }}$ Annual Conf Nigeria Society for Animal Production (NSAP) Ayetoro, Ogun State, Nigeria $248-51$. 
38. Ladeji O, Akin CU, Umaru HA (2004) Levels of antinutritional factors in vegetables commonly eaten in Nigeria. African J Natural Sci 7: 71-3.

39. Akindahunsi AA, Oboh G (1999) Effect of fermenting cassava with Rhizopus oryzae on the chemical composition of its flour and gari products. La Rivista Italiana Delle Sostanze Grasse 76: 437-40.

40. Wise A (1993) Dietary factors determining the biology activities of phytate nutrition. Abstract Rev Clini Nutr 53: $791-806$.

41. Valero M, Salmeron MC (2003) Antibacterial activity of 11 essential oils against Bacillus aureus in tyndallized carrot broth. Int J Food Microbiol 85: 73-81.

42. Tijani IDR, Jamal P, Alam MZ, Mirghani MES (2012) Optimization of cassava peel medium to an enriched material feed by the white rot fungus Panus tigrinus M609RQY. Inter Food Rese J 19: 427-32.

43. Aderemi FA, Nworgu FC (2007) Nutritional status of cassava peels and root seviate biodegraded with Aspergillus niger. American-Eurasian J Agric and Environ Sci 2: 308-11.

44. Nijveldt RJ, Van Nood E, Van Hoom DEC, Boelens PG, Van Norren K, et al. (2001) Flavoids: A review of probable mechanism of action and potential application. Am J Clin Nutr 74: 418-25.

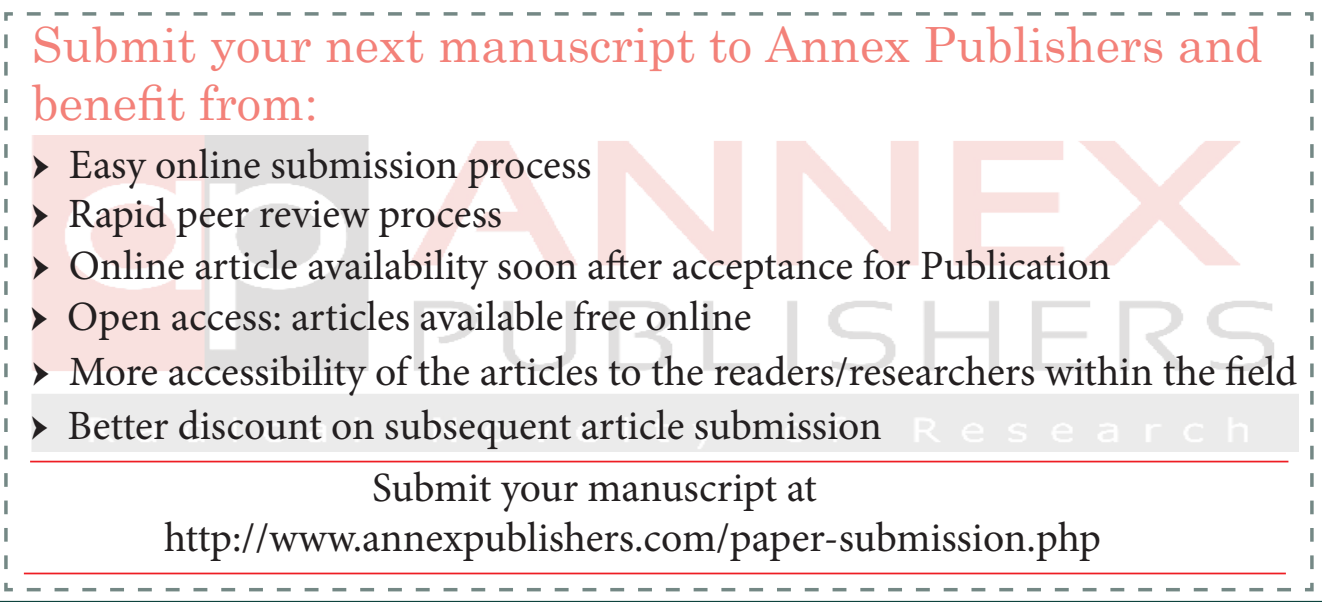

